Original Article

Open Access

\title{
COMMONLY ISOLATED ORGANISM IN DIABETIC FOOT AND ITS ANTIBIOTIC SENSITIVITY, AN EXPERIENCE AT TERTIARY CARE HOSPITAL
}

\author{
Muhammad Iqbal khan ${ }^{a}$, Riffat Arbab $^{b}$, Abdullah Khan $^{b}$, Maria Mehmood $^{b}$, Aisha Arshad ${ }^{c}$, Hafsa Jaffar $^{d}$, \\ Hafsa Qazi ${ }^{\mathrm{i}}$ \\ ${ }^{a}$ Assistant Professor, Department of Surgery/ Deputy Registrar (Admin), Post Graduate Medical Institute \\ Quetta Balochistan. \\ ${ }^{b}$ Assistant Professor, Department of Surgery, Bolan University of Medical \& Health sciences /Sandman \\ (Prov) Teaching Hospital, Quetta. \\ 'Post-Graduate Medical Resident, Surgical Unit-III, Sandman (Prov) Hospital, Quetta. \\ ${ }^{\mathrm{d} H o u s e}$ Surgeon, Department of Surgery, Sandman (Prov) Teaching Hospital, Quetta. \\ 'Post-Graduate Resident, Department of Surgery, Sandman (Prov) Teaching Hospital,Quetta.
}

\begin{abstract}
:
BACKGROUND \& OBJECTIVE: To determine the commonly isolated organism in ulcers of diabetic foot and its sensitivity to antibiotics.

METHODOLOGY: A total of 167 patients of diabetic foot were included in this descriptive Crosssectional study. All the patients were informed and consent was obtained according to ethical criteria approved by the ethical committee. The use of antibiotics in last 72 hours was strictly observed. The samples were obtained under aseptic conditions by applying the swab slightly to the exudate or base of the ulcer and were then carefully transferred in to the container and were then sent to the laboratory on the same date. The culture sensitivity was performed. Data was analyzed using SPSS. 20.
\end{abstract}

RESULTS: A total of 140 samples were positive for 8 types of bacteria out of 167.94 samples were monomicrobial were as 46 were polymicrobial. Over all Staphylococcus aureus 63(40.3\%) was the most commonly isolated bacteria followed by Pseudomonas aeruginosa $40(25.6 \%)$. S. aureus was most sensitive to imipenem/ meropenem (79.3\%) followed by vancomycin (71\%), linezolid $(69.8 \%)$ and moxifloxacin (69.8\%). P. aeruginosa was sensitive to impenem/ meropeneum (90\%) followed by Ticarcilline/ clavulante $(92.5 \%)$, amikacin $(87.5 \%)$ and pipracilline / tazobactom $(80 \%)$. Most of the gram positive and negative bacteria were resistant to commonly available antibiotic like ampiciline/ cloxacillin, amoxicilline/ clavulanate and cephradine.

CONCLUSION: Most of the commonly used antibiotics has developed resistance. S. aureus was most common bacteria from the isolates and was sensitive to impenem/meropenem, vancomycin and linezolid. Gram-negative bacteria showed sensitivity to impenem/meropeneum, pipracilline/ tazobactom, Ticarcilline/ clavulanate and amikacin.

KEYWORDS: Diabetic Foot, Diabetes Mellitus, Antibiotic Sensitivity.

doi: https://doi.org/10.37723/jumdc.v11i1.310

\section{How to cite this:}

Khan MI, Arbab R, Khan A, Mehmood M, Arshad A, Jaffar H, Qazi H. COMMONLY ISOLATED ORGANISM IN DIABETIC FOOT AND ITS ANTIBIOTIC SENSITIVITY, AN EXPERIENCE AT TERTIARY CARE HOSPITAL. jumdc. 2020;11(1):23-30.

doi: https://doi.org/10.37723/jumdc.v11i1.310

This is an Open Access article distributed under the terms of the Creative Commons Attribution License (http://creativecommons.org/licenses/by/4.0), which permits unrestricted use, distribution, and reproduction in any medium, provided the original work is properly cited. 


\section{INTRODUCTION:}

Diabetes mellitus is the leading cause of morbidity and mortality and responsible for 3.8 million deaths annually ${ }^{[1,2]}$, with a dramatic rise in number of new reported cases worldwide. The estimated numbers of cases in 2000 were 177 million, which rushed to 285 million in 2010. The estimated number of cases in 2030 will be 439 million ${ }^{[3,4,5]}$.

The mortality or morbidity of diabetes mellitus is associated with its long term complications ${ }^{[6]}$. Among its other complications, foot infection and ulceration is the major cause of hospitalization and amputation. The treatment of such patients is mainly dependent on proper assessment of host factors like renal and vascular impairment, reliable microbiological data and well assessment of severity of sepsis ${ }^{[4,}$

${ }^{7]}$. The pathogenesis of diabetic foot is basically neuropathic and vascular impairment which leads to loss of skin integrity with minor trauma followed by impaired healing ${ }^{[8,9,10]}$. Diabetic foot ulcers are one of the leading causes of hospital admissions and death among diabetic patient ${ }^{[6]}$. It is estimated that $15 \%$ of diabetic patients presents with diabetic ulcers and it's the leading cause of non-traumatic lower limbs amputation in United States ${ }^{[4,11]}$.

Well clinical assessment of ulcer with signs of infection and bone exposure, should always raise the suspicion of osteomyelitis. In such patients aggressive surgical debridement, proper I/V antibiotics and meticulous wound care can help to restore body's own bacterial barrier which can prevent amputations which is the most serious complications of such wounds $s^{[9,10,12]}$.

The organism found in these wounds differ not only in patient to patient and hospital to hospital but also from one part of the country to another ${ }^{[13,14,15,16]}$.

Selection of the appropriate antibiotic against specific organisms is one of the mainstays of treatment of such wounds. Curettage of the base of the foot ulcer and deep tissue are the reliable method to identify the specific organism and the antibiotic sensitivity ${ }^{[17,18]}$.

These diabetic foot ulcers are true emergencies and prompt diagnosis, surgical debridement and selecting appropriate antibiotic can improve the chances of limb salvage ${ }^{[4,13,15,19]}$.
Corresponding Author:

Dr. Muhammad Iqbal Khan,

Assistant Professor, of Surgery/Deputy Registrar

(Admin), Post Graduate Medical Institute Quetta

Balochistan.

Email: miqbaljaffar@gmail.com

Even in most sophisticated setup there is always delay in the laboratory results for culture and sensitivity, therefore the initial empiric therapy must be started as soon as possible ${ }^{[16,20]}$.

The aim of our work was to study the bacteriology of diabetic foot ulcers in patients presenting to Sandman Provincial Teaching Hospital Quetta, the relative frequency of bacteria isolated cultured from foot infection and to study their antimicrobial sensitivity to variety of commonly used antibiotics.

\section{METHODOLOGY:}

This cross-sectional descriptive study was conducted in the Department of Surgery Sandman (Prov) Teaching Hospital Quetta for a period of 02 years from July 2016 to June 2018. The study has been approved by the Ethical review committee of Sandman (Prov) Teaching Hospital Quetta. Convenient sampling technique was used for taking samples. A total of 167 patients were included in this study with well-established diagnosis of chronic diabetes mellitus that have foot ulcer at least from the last one month. Patients who had history of direct trauma, some sort of surgical debridement, any local or systemic antibiotic therapy were excluded from the study. The age of studied patients ranges from 35 to 85 years, 57 patients were male and 110 patients were female.

All the patients were informed and a written consent was taken first and demographic characteristics were noted. The specimens were collected. A swab was applied gently to the base of the ulcer or its exudate under aseptic conditions and then the swab was carefully transferred to the container. The container was then sent to laboratory on the same date and laboratory was requested for culture sensitivity test for most commonly used antibiotics. The results were then analyzed using SPSS 20 and were than presented in the form of tables. 


\section{RESULTS:}

A total number of 167 patients were included in our study out of which $57(34.1 \%)$ were male and $110(65.9 \%)$ were female as shown in table no. 1 . It was seen that the age of the patients ranges from 35 to 85 years of age with mean age of $68.09 \pm 9.85$ as shown in (Table-I).

Regarding duration of the ulcer, it was seen that $10(5.9 \%)$ patients had history of less than 10 days of ulcer duration, $99(59.3 \%)$ patients had 10 to 20 days of duration of ulcer and $58(34.8 \%)$ patients had 20 to 30 days of duration of ulcer. It was seen that $62(37.1 \%)$ patients had superficial ulcers of grade 1 and 2 were as $105(62.9 \%)$ patients had deep ulcer of Wagner grade 3,4 and 5. It was seen that out of 167 patients $27(16.2 \%)$ patients had shown no growth of bacteria, $94(56.3 \%)$ patients had shown monomicrobial growth and 46(27.5\%) patient had shown polymicrobial growth as shown in (Table-II).

It was studied that among Gram positive bacteria, Staphylococcus aureus was the most common bacteria $63(40.3 \%)$ were as Staphylococcus epidermidis was seen in $12(7.6 \%)$ samples only as shown in (Table-III). Similarly, among Gram negative bacteria Pseudomonas aeruginosa was most common $40(25.6 \%)$ were as Escherichia coli was second most common 30(19.2\%), Proteus was isolated from $5(3.2 \%)$ samples and Klebsiella was isolated from $6(3.8 \%)$ samples as shown in (Table-III).
In this study we have seen that Staphylococcus aureus was most sensitive to Imepenem/ Meropenem 50(79.3\%), the second most effective antibiotic for Staphylococcus aureus was seen to be vancomycin $45(71 \%)$ followed by Linezolid 44(69.8\%), Moxifloxacin 44(69\%) as shown in (Table-IV). Similarly, Staphylococcus epidermidis was seen to be more sensitive to Imepenem/Meropenem $10(83.3 \%)$ followed by vancomycin and Linezolid $9(75 \%)$ both as shown in (Table-IV). It was further studied that among gram negative bacteria pseudomonas aeruginosa was most sensitive to Ticarcilline/ clavulante $37(92 \%)$ followed by Imepenem/ meropeneum $36(90 \%)$, amikacin 35(87.5\%) and pipracilline/ tazobactom $32(80 \%)$. It was studied that E. coli was most sensitive to Imepenem/ meropenem $24(80 \%)$ followed by Ticarcilline/ clavulante $23(76.6 \%)$, pipracilline / Tazobactom $22(73.3 \%)$. It was also seen that proteus was most sensitive to Imepenem/ meropeneum $3(60 \%)$ and pipracilline/ tazobactom 3(60\%) followed by Ticarcilline/ clavulante $2(40 \%)$, amikacin 2(40\%), and moxifloxacin 2(40\%). It was seen further that Klebsiella was most sensitive to Imepenem/ meropenem and pipracilline / tazobactom 5(83.3\%) each followed by Ticarcilline/ Clavulante and moxifloxacin $4(66 \%)$ each as shown in (TableV).

Table-I: Demographic Features of the patients included in this study.

\begin{tabular}{|c|c|c|c|}
\hline \multirow{4}{*}{ Age } & Group & Number of Patients & Percentage \\
\cline { 2 - 4 } & $35-45$ Year & 16 & $9.5 \%$ \\
\cline { 2 - 4 } & $46-55$ Years & 3 & $1.8 \%$ \\
\cline { 2 - 4 } & $56-65$ Years & 47 & $28.2 \%$ \\
\cline { 2 - 4 } & $66-75$ Years & 43 & $25.6 \%$ \\
\cline { 2 - 4 } & $76-85$ Years & 58 & $34.9 \%$ \\
\cline { 2 - 4 } & Total & 167 & $100 \%$ \\
\cline { 2 - 4 } & Mean \pm S.D & \multicolumn{2}{|c}{$68.09 \pm 9.85$} \\
\hline \multirow{4}{*}{ Gender } & Male & 57 & $34.1 \%$ \\
\cline { 2 - 4 } & Female & 110 & $65.9 \%$ \\
\cline { 2 - 4 } & Total & 167 & 100 \\
\hline
\end{tabular}


Table-II: Pathological Features of the patients included in this study.

\begin{tabular}{|c|c|c|c|}
\hline $\begin{array}{c}\text { Pathological } \\
\text { Features }\end{array}$ & Grade of Ulcer & No. of Patients & Percentage \\
\hline \multirow{4}{*}{ Duration of Ulcer } & Less than 10 Days & 10 & $5.9 \%$ \\
\hline & 10 - 20 days & 99 & $56.3 \%$ \\
\hline & 20 - 30 days & 58 & $34.8 \%$ \\
\hline & Total & 167 & $100 \%$ \\
\hline \multirow{4}{*}{ Grade of Ulcer } & Grade of Ulcer & No. of Patients & Percentage \\
\hline & $\begin{array}{c}\text { Superficial } \\
\text { (Wagner 1\& 2) }\end{array}$ & 62 & $37.1 \%$ \\
\hline & $\begin{array}{c}\text { Deep } \\
\text { (Wagner } 3,4 \text { \& } 5)\end{array}$ & 105 & $62.9 \%$ \\
\hline & Total & 167 & $100 \%$ \\
\hline \multirow{5}{*}{$\begin{array}{l}\text { No. of Bacteria } \\
\text { Isolated }\end{array}$} & $\begin{array}{c}\text { No. of Bacteria per } \\
\text { patient }\end{array}$ & No. of Patients & Percentage \\
\hline & No. Growth & 27 & $16.2 \%$ \\
\hline & Monomicrobial & 94 & $27.5 \%$ \\
\hline & Polymicrobial & 46 & $56.3 \%$ \\
\hline & Total & 167 & $100 \%$ \\
\hline
\end{tabular}

Table-III: Isolated Bacteria $\mathrm{n}=156$.

\begin{tabular}{|c|c|c|c|}
\hline & No. of Bacteria & Frequency & Percentage \\
\hline \multirow{4}{*}{$\begin{array}{c}\text { Gram Positive } \\
\text { Bacteria } \\
\mathbf{n = 7 5}\end{array}$} & S. aureus & 63 & $40.4 \%$ \\
\cline { 2 - 4 } & S. epidermidis & 12 & $7.6 \%$ \\
\hline \multirow{3}{*}{$\begin{array}{c}\text { Gram Negative } \\
\text { Bacteria } \\
\mathbf{n = 8 1}\end{array}$} & P. aeruginosa & 40 & $25.6 \%$ \\
\cline { 2 - 4 } & E. coli & 30 & $19.3 \%$ \\
\cline { 2 - 4 } & P. mirabulus & 5 & $3.3 \%$ \\
\cline { 2 - 4 } & Klebsiella & 6 & $3.8 \%$ \\
\cline { 2 - 4 } & Total & 156 & 100 \\
\hline
\end{tabular}


Table-IV: Antibiotic Sensitivity for Gram Positive Bacteria.

\begin{tabular}{|l|c|c|}
\hline \multicolumn{1}{|c|}{ Antibiotics } & $\begin{array}{l}\text { Staphylococcus Aureus } \\
\mathbf{n = 6 3}\end{array}$ & $\begin{array}{l}\text { Staphylococcus } \\
\text { Epidermidis } \mathbf{n = 1 2}\end{array}$ \\
\hline Ampicillin-Cloxacillin & $22(34.9 \%)$ & $7(58.3 \%)$ \\
\hline Amoxicillin-Clavulanate & $39(61.9 \%)$ & $6(50 \%)$ \\
\hline Cephradine & $26(41.2)$ & $5(41.6 \%)$ \\
\hline Cefuroxime & $40(63.4 \%)$ & $8(66.6 \%)$ \\
\hline Ceftriaxone & $39(61.9 \%)$ & $5(41.6 \%)$ \\
\hline Cefepime & $40(63.4 \%)$ & $9(75 \%)$ \\
\hline Moxifloxacin & $44(69.8 \%)$ & $9(75 \%)$ \\
\hline Imepenem/Meropenem & $50(79.3 \%)$ & $10(83.3 \%)$ \\
\hline Flucloxacillin & $29(46 \%)$ & $5(41.6 \%)$ \\
\hline Methicillin & $33(52.3 \%)$ & $7(58.3 \%)$ \\
\hline Vancomycin & $45(71 \%)$ & $9(75 \%)$ \\
\hline Fusidic acid & $36(57.1 \%)$ & $7(58.3 \%)$ \\
\hline Linezolid & $44(69.8 \%)$ & $9(75 \%)$ \\
\hline
\end{tabular}

Table-V: Antibiotic Sensitivity for Gram Negative Bacteria.

\begin{tabular}{|c|c|c|c|c|}
\hline Antibiotics & $\begin{array}{c}\text { Pseudomonas } \\
\text { Aeruginosa }\end{array}$ & E. coli & Proteus & Klebsiella \\
\hline Ampicillin-Cloxacillin & $0(0 \%)$ & $0(0 \%)$ & $0(0 \%)$ & $0(0 \%)$ \\
\hline Amoxicillin-Clavulante & $2(5 \%)$ & $8(26.6 \%)$ & $1(20 \%) 2$ & $2(33.3 \%)$ \\
\hline Cephradine & $0(0 \%)$ & $0(0 \%)$ & $0(0 \%)$ & $0(2 \%)$ \\
\hline Cefuroxime & $4(10 \%)$ & $5(16.6 \%)$ & $0 \%$ & $0 \%$ \\
\hline Ceftriaxone & $28(70 \%)$ & $5(16.6 \%)$ & $1(20 \%)$ & $1(16.6 \%)$ \\
\hline Cefipime & $16(37.5 \%)$ & $7(23.3 \%)$ & $1(20 \%)$ & $3(50 \%)$ \\
\hline Moxifloxacillin & $24(60 \%)$ & $15(50 \%)$ & $2(40 \%)$ & $4(66.6 \%)$ \\
\hline Imepenam/Meropenam & $36(90 \%)$ & $24(80 \%)$ & $3(60 \%)$ & $5(83.3 \%)$ \\
\hline PippercillinTazobactem & $32(80 \%)$ & $22(73.3 \%)$ & $3(60 \%)$ & $5(83.3 \%)$ \\
\hline Ticarcillin-Calvulante & $37(92.5 \%)$ & $23(76.6 \%)$ & $2(40 \%)$ & $4(66.6 \%)$ \\
\hline Amikacin & $35(87.5 \%)$ & $20(66.6 \%)$ & $2(40 \%)$ & $3(50 \%)$ \\
\hline
\end{tabular}

\section{DISCUSSION:}

The pathogenesis of diabetic foot includes diabetic neuropathy, peripheral disease, high plantar pressure and minor traumas which goes un-noticed ${ }^{[4,5,21]}$. Once there is a breach in the skin, infection may occur due to impaired healing process in diabetic patients leading to infected ulcers. These infected ulcers do not get proper antibiotics due to poor understanding of commonly involved bacteria and their sensitivity to antibiotics ${ }^{[1,22]}$.

In our study we had seen that out of 167 patients $94(56.3 \%)$ patients had polymicrobial growth whereas $46(27.5 \%)$ patients had mono microbial growth, these results were close to a study conducted by Alavi SM et al ${ }^{[7]}$. Some other authors had similar results ${ }^{[23,24]}$. In comparison to study conducted by Anandi $\mathrm{C}$ et al had much higher rate of mono microbial infection ${ }^{[24]}$. This might be due to lower positive growth of organisms in our data.

In our study we have seen that gram negative bacteria (52\%) were commonly isolated as compared to gram positive bacteria (48\%). These results were close to other studies by Umaclevi $\mathrm{S}$ et al and other authors $[23,25,26,27]$. Overall S.aureus $(40.4 \%)$ was seen to be the 
most commonly isolated organism, similar results were seen in other studies as well ${ }^{[1,28,29,30]}$. It was further seen that Pseudomonas Aeruginosa was the most commonly isolated gram negative bacteria, accounting almost $25.6 \%$ which is close to results of other studies $^{[29,31,32,33]}$.

In our data it was studied that S.aureus was more sensitive to impenem/ meropenam $(79.3 \%)$ followed by vancomycin $(71 \%)$, moxifloxacin (69.8\%), linezolid [69.8\%] and Cefipime $(63.4 \%)$. It was also noted that S.aureus was resistant to more commonly available antibiotic like ampicillin /cloxacillin (39.9\%), Amoxacillin-Clavulanate (61.9\%) and methicillin (52.3\%), similar results were seen in other studies ${ }^{[1,4,5,25,26,27,34]}$. These results are may be due to improper and unchecked use of antibiotic by quakes in the periphery.

It was further seen that P.aeruginosum was most sensitive to Ticarcillin-clavulanate $(92.5 \%)$ followed by impenem /meropenam (90\%), Amikacin (87.5\%) and Pipracilline/ Tazobactom (80\%). These results were similar to other researches ${ }^{[10,23,34]}$. It was also observed that all the gram negative bacteria showed poor sensitivity to commonly available penicillin and cephalosporin. Similar patterns were studied in other study by Umadevi S et al ${ }^{[23]}$. This pattern of resistance is alarming and might be due to casual use of these easily available antibiotics in the market and easy access by everyone to them.

\section{CONCLUSION:}

We concluded that the treatment of the diabetic foot should be started with proper specimen collection for culture and sensitivity before starting the empirical antibiotic therapy. The empirical therapy should be started with combination of two antibiotics e.g. Vancomycin or Linezolid plus Imipenem/ Meropenem or a Cephalosporin. This combination should be changed later with results of the culture and sensitivity.

CONFLICT OF INTEREST: All authors disclose no conflict of interest.

\section{GRANT SUPPORT \& FINANCIAL}

DISCLOSURES: None.

\section{REFERENCES:}

1. Fawad R, Fahim U, Muhammad I. F. J Ayub Med Coll Abbottabad 2016;28(3):528-33.

2. The International Diabetes Federation. Diabetes epidemic out of control [online]. [cited 2006 Dec 4]. Available from: http://www.idf.org/node/1354? unode $=7 \mathrm{~F}$ 22 F 450 - B 1 E D - 43 B B - A 57 C B975D16A812D.

3. Shaw JE, Sicree RA, Zimmet PZ. Global estimates of the prevalence of diabetes for 2010 and 2030. Diabetes research and clinical practice. 2010 Jan 1;87(1):4-14.

4. Yoga R, Khairul A, Sunita K, Suresh C. Bacteriology of diabetic foot lesions. Med J Malaysia 2006;61:14-6.

5. Zubair M, Malik M, Ahmad J. Diabetic foot ulcer: a review. American Journal of Internal Medicine. 2015;3(2):28-49.

6. Powers AC. Diabetes mellitus. In: Fauci AS, Kasper DL, Longo DL, Braunwald E, Hauser $\mathrm{SL}$, Jameson JL, et al, editors. Harrison's Principles of Internal Medicine. 17th ed. New York: The McGraw-Hill; 2008. p.2276-92.

7. Alavi, M.S., D.A. Khosravi, A. Sarami, A. Dashtebozong and Montazeri A.E. 2007. Bacteriologic study of diabetic foot ulcer. Pak. J. Med. Sci. 23(5):681 684.

8. Boulton, A.J., 2002. The diabetic foot: a global view. Diabetes Metab. Re.s Rev. 16(suppl 1):S2 S5.

9. Boulton, A.J.M., L. Vileikyte, G. RagnarsonTennvall and Apelqvist, J. 2005. The global burden of diabetic foot disease. Lancet. 366:1719 1724.

10. Ndosi M, Wright Hughes A, Brown $S$, Backhouse $M$, Lipsky BA, Bhogal $M$, Reynolds C, Vowden P, Jude EB, Nixon J, Nelson EA. Prognosis of the infected diabetic foot ulcer: a 12 month prospective observational study. Diabetic Medicine. 2018 Jan;35(1):78-88.

11. Centers for Disease Control and Prevention. National diabetes fact sheet: national estimates and general information on diabetes and prediabetes in the United 
States, 2011. Atlanta, GA: US department of health and human services, centers for disease control and prevention. 2011 Jan;201(1):2568-9.

12. Kee KK, Nair HK, Yuen NP. Risk factor analysis on the healing time and infection rate of diabetic foot ulcers in a referral wound care clinic. Journal of wound care. 2019 Jan 1;28(Sup1):S4-13.

13. El-Tahawy AT. Bacteriology of diabetic foot infections. Saudi medical journal. 2000 Jan;21(4):344-7.

14. Lipsky BA, Berendt AR, Deery HG, Embil JM, Joseph WS, Karchmer AW, et al. Diagnosis and treatment of diabetic foot infections. Clin Infect Dis 2004;39(7): 885-910.

15. Wu L, Hou Q, Zhou Q, Peng F. Prevalence of risk factors for diabetic foot complications in a Chinese tertiary hospital. Int J Clin Experimental Med. 2015;8(3):3785.

16. Min Liu, Wei Zhang, Zhaoli Yan, and Xiangzhen Yuan. Smoking increases the risk of diabetic foot amputation: A metaanalysis. Experimental and Therapeutic Medicine 2018 Feb; 15(2): 1680-1685.

17. Frykberg RG, Zgonis T, Armstrong DG, Driver VR, Giurini JM, Kravitz SR, Landsman AS, Lavery LA, Moore JC, Schuberth JM, Wukich DK. Diabetic foot disorders: a clinical practice guideline (2006 revision). The journal of foot and ankle surgery. 2006 Sep 1;45(5):S1-66.

18. Ismail Lawal Dahiru, Kenneth Ezenwa Amaefule, Innocent Onaja Okpe, Abdulrasheed Ibrahim and Salisu Babura Muazu. An overview of diabetic foot disease. Nigeria Journal of Basic and clinical sciences 2016 Vol. 13 Issue $1 \mathrm{Pg}$ 1-12.

19. Pengzi Zhang, Jing Lu, Yali Jing, Sunyi Yan Tang, Dalong Zhu and Yan Bi. Global epidemiology of diabetic foot ulceration: A systematic review and meta-analysis. Annals of medicine Vol. 49, 2017 Issue 2.

20. Toscano CM, Sugita TH, Rosa MQ, Pedrosa HC, Rosa RD, Bahia LR. Annual direct medical costs of diabetic foot disease in Brazil: a cost of illness study. International journal of environmental research and public health. 2018 Jan;15(1):89.

21. Frykberg RG, Armstrong DG, Giurini J, Edwards A, Kravette M, Kravitz S, et al.
Diabetic foot disorders: A clinical practice guideline. American College of Foot and Ankle Surgeons. J Foot Ankle Surg 2000;39(5):51-60.

22. Lipsky BA, Aragón Sánchez J, Diggle M, Embil J, Kono S, Lavery L, Senneville É, Urbančič Rovan $\mathrm{V}$, Van Asten S, Peters EJ, International Working Group on the Diabetic Foot (IWGDF). IWGDF guidance on the diagnosis and management of foot infections in persons with diabetes. Diabetes/Metabolism Research and Reviews. 2016 Jan;32:45-74.

23. Umadevi S, Kumar S, Joseph NM, Easow JM, Kandhakumari G, Srirangaraj S, et al. Microbiological study of diabetic foot infections. Indian J Med Spec $2011 ; 2(1): 12-7$.

24. Anandi C, Alaguraja D, Natarajan V, Ramanathan M, Subramaniam CS, Thulasiram M, et al. Bacteriology of diabetic foot lesions. Indian J Med Microbiol 2004;22(3):175-8.

25. Gadepalli R, Dhawan B, Sreenivas V, Kapil A, Ammini AC, Chaudhry R. A clinicomicrobiological study of diabetic foot ulcers in an indian tertiary care hospital. Diabetes care 2006;29:1727-32.

26. Umadevi S, Kumar S, Joseph NM, Easow JM, Kandhakumari G, Srirangaraj S, et al. Microbiological study of diabetic foot infections. Indian J Med Spec 2011;2(1): 12-7.

27. Chincholikar DA, Pal RB. Study of fungal and bacterial infections of the diabetic foot. Indian J Pathol Microbiol 2002;45(1): 15-22.

28. Raja NS. Microbiology of diabetic foot infections in a teaching hospital in Malaysia: a retrospective study of 194 cases. Journal of microbiology immunology and infection. $2007 \mathrm{Feb} ; 40(1): 39$.

29. Mantey I, Hill RL, Foster AV, Wilson S, Wade J], Edmonds ME. Infection of foot ulcers with Staphylococcus aureus associated with increased mortality in diabetic patients. Commun Dis Public Health 2000;3(4):288-90.

30. Abdulrazak A, Bitar ZI, Al-Shamali AA, Mobasher LA. Bacteriological study of diabetic foot infections. J Diabetes Complications 2005;19(3):138-41. 
31. Khoharo HK, Ansari S, Qureshi F. Diabetic foot ulcers. Professional Med J 2009;16(1):53-60.

32. Bansal E, Garg A, Bhatia S, Attri AK, Chander J. Spectrum of microbial flora in diabetic foot ulcers. Indian J Pathol Microbiol 2008;51(2):204-8.

33. Sharma VK, Khadka PB, Joshi A, Sharma R. Common pathogens isolated in diabetic foot infection in Bir Hospital. Kathmandu Univ Med J 2006;4(3):295-301.

34. Goldstein EJ, Citron DM, Nesbit CA. Diabetic foot infections. Bacteriology and activity of 10 oral antimicrobial agents against bacteria isolated from consecutive cases. Diabetes Care 1996;19(6):638-41.

\section{Authors' Contribution:}

Muhammad Iqbal khan: Study Design and final approval of manuscript.

Riffat Arbab: Data collection, statistical analysis and literature search.

Abdullah Khan: Over all Supervision of data collection, analysis and manuscript writing.

Maria Mehmood: Help in data collection analysis and final draft of study.

Aisha Arshad: Help in data collection analysis and final draft of study.

Hafsa Jaffar: Manuscript writing and proof reading.

Hafsa Qazi: Manuscript writing and data collection.

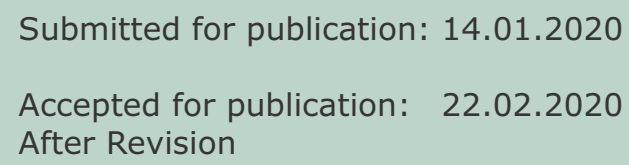

Failures are often the results of timidity and fears; disappointments are the results of bashfulness; hours of leisure pass away like summer-clouds, therefore, do not waste opportunity of doing good

\author{
Hazrat Ali (Karmulha Wajhay)
}

